Open Access

\title{
Defining the Black and Scholes approach: a first systematic literature review
}

Manlio Del Giudice ${ }^{1}$, Federica Evangelista ${ }^{2^{*}}$ and Matteo Palmaccio ${ }^{2}$

\author{
* Correspondence: \\ f.evangelista@unicas.it \\ 2Department of Business and Law, \\ University of Cassino and Southern \\ Lazio, Via S. Angelo, Loc. Folcara, \\ Cassino, Italy \\ Full list of author information is \\ available at the end of the article
}

\begin{abstract}
Purpose: The aim of the paper is to investigate the Black and Scholes model by providing an updated framework of the international literature on the topic, within the field of real option. The purpose of the research is to identify the relevant literature between 1999 and 2015, together with the most important perspectives on the Black and Scholes model as analysed by scholars, in order to provide a useful support to the academic community in their studies. The investigation was carried out only for its economic and corporate insights, with the objective of establishing the strong and weak points highlighted in the defined framework.

Methodology: The method used for the research was based on qualitative approach. International literature on the topic was examined through a research protocol. The research was developed by the identification of four keywords (Real Options Valuation, Real Options Assessment, Black and Scholes, Real Options Pricing) and searching them in two databases, with the purpose of obtaining a wide range of scientific contribution for the analysis.
\end{abstract}

Originality/value: The paper presents an accurate review of the scientific contribution on the topic of the Black and Scholes model; it defines the fields of application, opportunities offered and issues relating to its application, in order to clarify the strong and weak points of the model.

Practical implications: The Black and Scholes model of the 1970s is acknowledged to be the most widely used model for evaluating options. Our study shows that this method has been adopted by decision-makers not only for evaluating options but also in other fields.

Keywords: Real options valuation, Real options assessment, Black and Scholes, Real options pricing

\section{Background}

In an economic environment defined by great uncertainty, rapid change and the need for flexibility, it has become increasingly important for corporate managers and decisionmakers to use investment assessment tools and processes that can give a correct representation of both uncertainty and the company's ability to react to new information.

In this scenario, real options (Adair et al. 2002; Bulan, 2005; Makhudu, 2011) have emerged as an approach that addresses this challenge more successfully than traditional capital budgeting techniques.

The real options analysis is so effective in the current business climate because of its explicit recognition process according to which future decisions designed to maximize

(C) 2016 Del Giudice et al. Open Access This article is distributed under the terms of the Creative Commons Attribution 4.0 International License (http://creativecommons.org/licenses/by/4.0/), which permits unrestricted use, distribution, and reproduction in any medium, provided you give appropriate credit to the original author(s) and the source, provide a link to the Creative Commons license, and indicate if changes were made. 
value will depend on new information that will not be available or possible to obtain until after the initial investment has been made (Del Giudice et al., 2014; Dotsis et al., 2012; Fanklin \& Diallo, 2012; Hult et al., 2010, Lankton \& Luft, 2008).

It is in this sense, that real options recall financial options. If on one hand the value of a stock option, and the investor's decision to exercise ti, dependson the future stock price, on the other hands, the decision about whether to exercise a real option is based on the future value of an underlying real asset or on the future value of an investment project.

Several approaches have been developed over the years to calculate the real options value of an investment (Ashuri et al., 2012; Benaroch \& Kauffman, 1999; Bulan et al., 2009; Denison et al., 2012; Kim et al., 2013, Krychowski \& Quélin, 2010), a project (Benaroch \& Kauffman, 1999; Brennan \& Trigeorgis, 2000; Eschenbach et al., 2007; Kodukula \& Papudesu, 2006; Mattar \& Cheah, 2006) or of managing a customer relationship (Del Giudice et al., 2013 Burnetas \& Ritchen; 2005; Henseler \& Romer, 2013).

Among these methods, the Black and Scholes model is the most widely applied in many fields, not only for evaluating financial options.

In order to define a general framework of application and gain a better understanding of this financial evaluation method, its fields of application, the opportunities offered and the relative open issues, the aim of our paper is to formulate an updated conceptualization of the scientific contributions produced over the period between 1999 and 2015 related to business and economic perspectives.

The research methodology is of qualitative nature. The study proposes the scientific contribution of the last sixteen years researching four key words (Real Options Evaluation, Real Options Assessment, Black and Scholes, Real Options Pricing) in two database (Google Scholar and EBSCO). In particular, the scientific contributions on the topic are searched, collected and analysed in order to propose the following literature review.

The structure of the paper is the following. After the "Background" section, the "Literature review" section contains the analyses of literature on real options assessment and real options evaluation. The "Results and discussion" section describes the research results. The "Conclusions" section illustrates the final consideration, the limitations and future perspectives of the study.The "Methods" section includes the methodology used in the study.

\section{Literature review}

\section{The real options evaluation and real options assessment}

In the current economic scenario, with its high levels of uncertainty, it is more complex to evaluate either the projects planned by the company or its investments, especially those connected to research and development.

When the flow of revenue and/or financing is impossible to determine for certain, this reduces the use of evaluative methods based these elements. Therefore, the real options-based method (Grullon et al., 2012) is defined as a method suited to evaluating these assets. While the method still retains the rational objectivity and neutrality that are typical of traditional evaluation techniques, it is certainly more suited to evaluating the opportunities offered by investments where the level of risk is high (Akdoğu \& MacKay, 2008; Denison et al., 2012; Favato, 2008). 
The term option is generally used for a contract where the buyer is given the right to purchase or to sell a given financial asset at a previously defined price. The party buying a call option acquires the right, if the option is exercised, to receive the asset on the predefined date and at the contractually defined price. On the other hand, the party that buys a put option has the right to receive the asset at the negotiated price at the expiry date of the contract after exercising the option.

Independently of whether it is a put option or a call option, the option is exercised, or if not, it is in function of the price of the asset at the expiry date of the contract.

The asset underlying the option perspectives is different from traditional financial assets, such as, for example, investments or projects; this is where real options come in Amram and Kulatilaka (1999) state that the analysis of investments in the perspective of real options is effective when:

- The value of the investment is heavily affected by contingent events

- The uncertainty inherent in the investment subject to evaluation makes it desirable to wait for further information

- The value of the investment could be subject to variation in the event of certain strategies

- The investment is particularly flexible

- The investment allows for corrections in progress

Following the statements made by the authors, real options can be classed into:

- Real options of development

- Real options of deferment

- Real options of flexibility

- Real options of abandonment

With these types of real options, it can be deduced that it is impossible to adopt a univocal and definitive classification scheme, which also confirms that investment evaluation methods cannot be used to evaluate autonomously the opportunities inherent in this kind of investment, making it necessary to adopt alternative models of evaluation.

The mathematical models used most widely to evaluate real options are the Cox, Ross and Rubinstein model (1985), the Black and Scholes model (1973) and the Merton model (1973).

The Cox, Ross and Rubinstein (1979) model is a multi-period binomial model for evaluating real options that derives from the generalization of the one-period binomial model. The model revised and completed by Cox and Rubinstein (1985) is one of the most effective methods to estimate the value of options. This model is based on a discrete approach in which the time to maturity of the option is divided into periods, within which the price of the underlying share $(S)$, which follows a lognormal distribution, can only take two alternative values: a favourable one that corresponds to a multiplier identified with the letter $h$ from high and an unfavourable one, identified with the letter $b$ from basso (= down).

As a consequence, this is as if $S$ were multiplied by $h(S(1)=h S(0)$ with $h>1)$ or by $b(S(1)=b S(0)$ with $0<b<1)$. 
The probability that the value is high $(h)$ is $p$ and that the value is low $(b)$ is $(1-p)$.

Every rise or reduction will annul the preceding reduction or rise, that is:

$$
h b=1
$$

In 1973, Black and Scholes (Black and Scholes, 1973) made a major breakthrough by deriving a differential equation that must be satisfied with the price of any securitydependent derivative on a non-dividend-paying stock.

The basic assumptions of the model are the following:

1. Markets are always open.

2. There is no cost arbitrage.

3. Risk-free interest rate is constant over time.

4. The volatility of the price of the underlying asset is constant.

5. The price movements of the underlying asset follow a lognormal distribution, which implies a normal distribution of capitalized returns.

6. The underlying asset does not pay dividends.

For risk-neutral investors, the Black-Scholes pricing formula for a call option is

$$
c=S_{0} \times N\left(d_{1}\right)-X e^{-i_{1} T} \times N\left(d_{2}\right)
$$

where

$$
\begin{aligned}
& d_{1}=\frac{\ln \left(\frac{S_{0}}{X}\right)+\left(i_{1}+\frac{\sigma^{2}}{2}\right) T}{\sigma \sqrt{T}} \\
& d_{2}=d_{1}-\sigma \sqrt{T}
\end{aligned}
$$

and where

$C_{0}$ is the option price.

$S_{0}$ is the current stock price.

$N(d)$ is the probability that a random draw from a standard normal distribution will be less than $d$.

$X$ is the exercised price.

$i_{1}$ is the annual continuous compound rate of return on a safe asset with the same maturity as the expiration of the option.

$T$ is the time to maturity of the option (in years).

$\sigma$ denotes the standard deviation of the annual continuous compound rate of return of the stock.

Merton (1973) extended the Black-Scholes option pricing formula to dividend-paying stocks as

$$
\begin{aligned}
& c=S_{0} e^{-\delta T} \times N\left(d_{1}\right)-X e^{-i_{1} T} \times N(d 2) \\
& d_{1}=\frac{\ln \left(\frac{S_{0}}{X}\right)+\left(i_{1}-\delta+\frac{\sigma^{2}}{2}\right) T}{\sigma \sqrt{T}} \\
& d_{2}=d_{1}-\sigma \sqrt{T}
\end{aligned}
$$

where $\delta$ are the dividends paid out during the lifetime of the option. 


\section{Results and discussion}

The Black and Scholes formula is the most widely known model used for evaluating options options (Adner \& Levinthal, 2004; Kogut \& Kulatilaka, 2004; Lele et al., 2014; Morris \& Limon, 2010; Pomykacz \& Olmsted, 2013; Wanetick, 2013). It has been used since the 1970s (Black and Scholes, 1973) to demonstrate that its results, under particular conditions (boundary conditions), are very similar to those obtained using the binomial model.

For the period between 1999 and 2015, we found that this method has been applied to many cases and in many different fields, from the evaluation of construction projects (Barton \& Lawryshyn, 2011; Ford et al., 2002; Garg \& Kumar, 2014; Jiao et al., 2007; Oppenheimer, 2002; Parthasarathy \& Madhumathi, 2010; Sewalk \& Dai, 2014); investments in R\&D (Kumaraswamy, 1996; Ming-Cheng \& Yen, 2007), in particular those by pharmaceutical companies (Gunther McGrath and Nerkar, 2004; Hartmann \& Assan, 2006); the evaluation of IT (information technology) projects (Benaroch, 2002; Fichman, 2004); insurance portfolio strategies; customer relationship management (Maklan et al., 2005); the management and evaluation of intagible assets (Bhattacharya \& Wright, 2005, Faiferlick et al. 2004, Park et al., 2013); and the assessment of bonds and derivatives (Driffill et al., 2013; Ericsson \& Reneby, 2005; Fabozzi et al., 2012, Pyo, 2008; Ren-Raw et al., 2002; Singh, 2014, Tompkins, 2001).

In the intervening period since the term real options was coined, over 32 years ago, several other approaches have been proposed for calculating the value of real options, producing very extensive literature on the topic, which span a wide range of subjects and fields.

Our research demonstrates that the Black and Scholes model and other real options evaluation models have been applied to meet the many needs linked to assessment and prediction of values.

Researching the four key words (Real Options Valuation, Real Options Assessment, Black and Scholes, Real Options Pricing) trough the two databases, Google Scholar and EBSCO, the results of 729 product has been obtained.

From the initial number, 263 contributions were extrapolated relating to economic and corporate perspectives. These are shown in the following Tables 1 and 2, for the two databases.

By applying the key words to the Google Scholar databases 240 scientific contributions are identified. The data obtained are processed according to the following Table 1.

Among the 240 scientific products, 109 are connected to business and administration, 31 are available and 17 related to more keywords, and a total of 21 scientific contributions are analysed.

Table 1 Google Scholar searching

\begin{tabular}{llllll}
\hline Keywords & $\begin{array}{l}\text { Total results } \\
\text { retrieved from } \\
\text { analysed database }\end{array}$ & $\begin{array}{l}\text { Economic and } \\
\text { corporate } \\
\text { purposes }\end{array}$ & \begin{tabular}{l} 
Available on the analysed database \\
\cline { 4 - 5 } Focus of the \\
present study
\end{tabular} & Related to more keywords & 21 \\
\hline Real options valuation & 60 & 39 & 9 & 5 & 0 \\
Black and Scholes & 60 & 15 & 3 & 3 \\
Real options assessment & 60 & 17 & 15 & 9 \\
Real options pricing & 60 & 38 & 31 & 17 \\
\hline
\end{tabular}


Table 2 EBSCO searching

\begin{tabular}{|c|c|c|c|c|c|}
\hline \multirow[t]{2}{*}{ Keywords } & \multirow{2}{*}{$\begin{array}{l}\text { Total results } \\
\text { retrieved from } \\
\text { analysed database }\end{array}$} & \multirow{2}{*}{$\begin{array}{l}\text { Economic and } \\
\text { corporate } \\
\text { purposes }\end{array}$} & \multicolumn{2}{|c|}{ Available on the analysed database } & \multirow{2}{*}{$\begin{array}{l}\text { Focus of the } \\
\text { present study }\end{array}$} \\
\hline & & & Total & Related to more keywords & \\
\hline Real options valuation & 120 & 48 & 33 & 7 & 84 \\
\hline Black and Scholes & 120 & 20 & 14 & 0 & \\
\hline Real options assessment & 120 & 41 & 16 & 6 & \\
\hline \multirow[t]{2}{*}{ Real options pricing } & 120 & 45 & 30 & 3 & \\
\hline & 480 & 154 & 93 & 16 & \\
\hline
\end{tabular}

The following Table 2 shows data concerning the EBSCO databases.

We retrieved 480 results from the EBSCO database, of which 154 related to economic and business purpose, 93 were available and 16 related to more keywords. In total, 84 scientific products are analysed.

In addition, 125 contributions are used for defining the state of art, to analyse the existing schools of thought.

All 263 contributions relating to economic and corporate purpose are analysed to obtain the quantitative data concerning the type of scientific production.

Over the period analysed (1999-2015), the existing literature can be classified into articles, 144 contributions; books, ten contributions; citations, five contributions; and book chapters, one contribution (Table 3).

After the first step of analysis, we are able to classify the scholars' contributions according to the topics investigated.

Some authors (Avanzi et al., 2013; Baduns, 2013) argued for the utilization of real options theory in the field of decision-making (Yonggang and Mingli, 2014; McCarter et al., 2011). Benaroch and Kauffman (1999), for example, used this theory to solve problems in IT investment decisions.

Other authors tried to validate real options theory (Triantis and Borison, 2001) or fill a gap in the theory (Peng, 2010).

The real options model can also be used in portfolio selection and management, as well as in portfolio or project or asset assessment. Wang and Hwang (2007) applied the theory to the R\&D portfolio decision, while Moore and Juh (2006) used daily data on warrants traded on the Johannesburg Stock Exchange between 1909 and 1922 to test how close derivative prices are to Black and Scholes' (1973) prices and to compute profits for investors using a simple trading rule for call options.

Strategic decisions, such as entry to new markets, have at their core companyspecific risks. The basic question is whether an investment or entry to a new area has the potential of helping a company protect its future earning streams from industry and macro-economic pressures reflected in market portfolio returns. If such entry contributes to competitive advantage, investment in the area is valuable, a conclusion that is not controversial (Porter, 1980). However, it is important to consider the scope of opportunity, potential access to other avenues of growth or, in other words, the variance underlying such investments.

Table 3 First research results

\begin{tabular}{llll}
\hline Articles & Books & Citations & Chapters of book \\
\hline 147 & 10 & 5 & 1 \\
\hline
\end{tabular}


The real options perspective offers a complementary approach to models of investments under uncertainty borrowed from the field of finance (Fama and French, 1996) and behavioural theories of decision-making.

More specifically, real options reasoning could be used to bridge the uncertainty relating to innovation investment decisions that take a company into new technological areas.

The real options perspective could distinguish the initial foray into a new technological area, such as a real option, which creates a somewhat proprietary opportunity for the investing firm to make later decisions, such as to further exploit or to exit the area (Trequattrini et al., 2012a).

Kogut (1991) and Bowman and Hurry (1993) are early advocates of resolving the tension between the rationality of finance-based models and the observations of behavioural researchers seen through an options lens. As the authors point out, optionsthinking accommodates the value of flexibility, differing resource allocation horizons, the process of retrospective sense-making and path dependence. In this paper, we support an options perspective by describing the investment strategies of a group of firms (Maggioni and Del Giudice 2011).

By applying the real options model, decision-makers implicitly (or explicitly) respond to the value of their right to preserve decision rights in the future for their investment choices and in their theoretical investment behaviour.

This model should be used to identify certain investment decisions as amenable to the real options perspective and then examine the evidence concerning whether actual investment patterns are consistent with the predictions of real options theory.

Such analyses have been conducted in this field in respect to joint ventures (Kogut, 1991), international entry decisions (Chi and McGuire, 1996), governance choices in collaboration (Folta, 1998), foreign direct investment decisions (Kogut and Kulatilaka, 1994) and R\&D investments (Kumaraswamy, 1996).

It suggests that the real options model has much to contribute to a theory of investment in the field of strategy (Lombardi et al., 2014).

Projects, including IT projects, typically use the Black and Scholes model to value real options that arise from the capability managers have in influencing cash flows for projects under their control.

Discounted cash flow (DCF) techniques are standard methods used for the evaluation of capital budgeting projects. Under DCF, the expected cash inflows and outflows from a project are stated in present value terms by using a discount rate selected to account for the project's risk and the time value of money. The DCFs are summed, and investment costs are subtracted to obtain the net present value (NPV) of the project. Theory holds that if the NPV is positive, the project should be undertaken to increase shareholder value.

The assumption that all investments are irreversible (Trequattrini et al., 2012b) is a fundamental weakness of most DCF methods. Managers often have the ability to influence the results of a project and have recourse to abandoning a project if results are poor, while retaining the opportunity of expanding projects (Palacios-Marqués et al. 2015, Soto-Acosta et al. 2010) if results are better than expected. This managerial flexibility is not valued with the traditional NPV method.

Option pricing theory offers a supplement to the NPV method, considering in addition managerial flexibility in making decisions regarding the real assets of the firm. 
Managers' options on real investment projects are comparable to investors' options on financial assets, such as stocks.

Just as a financial option derives much of its value from the potential price movements of the underlying financial asset, a real option derives much of its value from the potential fluctuations of the cash flows generating the value of the investment project.

Success of this method depends on the ability to provide a quick estimation of the value of a real option using a limited range of inputs. Nevertheless, there are some criticisms:

1. According to many contributions (Huang and Chen, 2002), this method is only reliable under very restrictive conditions.

2. In part of the doctrine (Triantis and Borison, 2001), the binomial option pricing model is considered to be more flexible in allowing the optimal timing of the decision to exercise.

3. In some contributions (Damodaran 2000), the Black and Scholes formula is considered as an easy way to get a roughly reliable value just for simple investment opportunities, with the limitation of a specific date to exercise.

4. Some authors criticize the real options approach. Borison (2005) analysed the applicability of the approach, the major assumptions and the steps involved in putting the approach into use.

Concluding, we find that real options models are used in risk analysis both to demonstrate the importance of the "option to wait" due to uncertainty over future shocks to project cash flows (Baker et al. 2011; Grasselli, 2011) and because of the uncertainty (Farrow, 2004; Henderson \& Hobson, 2002) about the permanence of past shocks.

After finding 263 contributions relating to economic and corporate purpose, of which 42 were duplicates, we were left with 221 contributions on real options theory relating to economic and corporate purpose.

It is possible, under the previous assumptions, to classify the existing literature by the main topics in Table 4.

\section{Conclusions}

The term "real options" was coined by Stewart Myers in 1977. It referred to applying option pricing theory to the valuation of non-financial or "real" investments with learning and flexibility, such as multi-stage R\&D and modular manufacturing plant expansion (Myers, 1977). The topic attracted academic interest between 1980 and 1990, and articles on the theory and its applications were published.

Table 4 Second research results

\begin{tabular}{ll}
\hline Research topics & Scientific contributions \\
\hline Decision-making & 42 \\
Validation of real options theory & 30 \\
Criticize real options approach & 4 \\
Portfolio selection and management & 33 \\
Valuation of asset/project/investment & 92 \\
Analysis of the risk & 20 \\
& 221 \\
\hline
\end{tabular}


Beginning in the mid-1990s, interest in the concepts of value and the techniques of valuation increased substantially. Real options began to attract considerable attention from industry as a potentially important tool for valuation and strategy.

Several practitioner books on the topic have appeared, and more are in progress. All things considered, real options have made the transition from a topic of modest academic interest to one that attracts considerable, active academic and industry attention.

A variety of contradictory approaches have been suggested for implementing real options in practice.

Real options in option-thinking are based on the same principles as financial options. In real options, the options involve "real" assets as opposed to financial ones. Having a "real option" means having the possibility, for a certain period, to choose either for or against making an investment decision, without binding oneself up front. For example, owning a power plant gives a utility company the chance, but not the obligation, to produce electricity at some later date.

Therefore, real options can be valued using the analogue option theories that have been developed for financial options, which are quite different from traditional DCF investment approaches.

The aim of the paper is to investigate the literature review on the real options model, through a quantitative study on the literature produced between 1999 and 2015 and an updated concept of the topic by classifying the contributions on the topic. The final objective of the analysis is to propose a new research perspective on the Black and Scholes method in economic and corporate perspectives.

As found in the analysis, the main topic of the contribution is the application of the real options model to evaluate assets, projects and investments. This is followed by the use of the model for the following: decision-making purposes (42), portfolio selection and management (33), validation of real options theory (30), risk analysis (20) and criticizing the real options approach (4).

In this way, the paper provides quantitative data about the production of literature, by identifying the strong and weak points of the literature analysed for the academic community.

According to the quantitative data, we are able to present the evolution of literary production during the period between 1999 and 2015. More specifically, we divided the contributions into the following categories: articles, books and citations.

By analysing the selected literature, it is possible to identify the main applications of this method within business administration, by offering new spaces to be filled with literary production.

The paper presents some limitations: it analysed the literature production between 1999 and 2015 and then only the first six pages obtained from the two databases EBSCO and Google Scholar.

Future studies could be conducted in order to analyse a wider time period and by applying the keywords to more databases.

\section{Methodology}

The research on Black and Scholes Model is developed through a qualitative methodology (Maylor and Blackmon, 2005; Myers, 2013). The existing studies on the topic are retrieved by analysing international literature. More specifically, we have chosen to 
search four key words in two databases such as Google Scholar and EBSCO; the results have been based on several retrieved publications.

Particularly, the keywords used to set up the literature review are the following:

1. Real Options Valuation;

2. Real Options Assessment;

3. Black and Scholes;

4. Real Options Pricing.

Data are acquired through a search protocol, which is required for processing structured data.

The research protocol involves the following steps:

1. identification of the study objective through the elaboration of a project summary report;

2. definition of procedures for data collection and assignation of tasks to each member of the working group. The working group, consisting of three people, was involved in the research of secondary data;

3. definition of guidelines to prepare a study report highlighting the essential points of the project.

The contributions analysed are mainly articles, books and citations.

In order to restrict our research to more recent studies, we selected the period from 1999 to 2015 and, for each keyword search, we analysed the first six pages of results, therefore avoiding any loss of relevance in the results.

We obtained 240 hits for Google Scholar and 480 for EBSCO.

From the initial number of 720 contributions, we extrapolated 263 scientific products connected to the economic and corporate perspectives.

\section{Competing interests}

Manlio Del Giudice is Associate Professor of Business Management at the University of Rome "Link Campus", where he serves as Associate Dean of the Faculty of International Business Management. He is also Professor of Management of Biotech Firms at the "Federico II" University of Naples and Affiliate Professor of Business Management and Entrepreneurship at the Paris Business School, in Paris. His research interests focus on knowledge management, crosscultural management, family business management, and entrepreneurship.

Federica Evangelista is Ph.D. student in Business Administration, Department of Economics and Law at the University of Cassino and Southern Lazio (Italy). Her main research interests are business administration, business management, corporate governance, corporate social responsibility, intellectual capital and intellectual property rights, intellectual asset management and knowledge management, international accounting, leadership.

Matteo Palmaccio is a Ph.D student in Business Administration, Department of Economics and Law at the University of Cassino and Southern Lazio (Italy). His main research interests focus on corporate disclosure, intellectual capital, international accounting, corporate insolvency, business evaluation.

\section{Authors' contributions}

This paper is the joint work of the three authors: the "Background " and "Conclusion" are by MDG, the "Literature Review" and "Methodology" paragraphs are by FE, the paragraph entitled "Results and discussion" is by MP. All authors read and approved the final manuscript.

\section{Author details}

${ }^{1}$ ESG Management School, Paris School of Business, 59 Rue Nationale, 75013 Paris, France. ${ }^{2}$ Department of Business and Law, University of Cassino and Southern Lazio, Via S. Angelo, Loc. Folcara, Cassino, Italy. 


\section{References}

Adair, A., Kawaguchi, Y., \& Tsubokawa, K. (2002). The pricing of real options, briefings. Real Estate Finance, 2(1), 90-94. Adner, R., \& Levinthal, D. A. (2004). Real options and real tradeoffs. Academy of Management Review, 29(1), 120-126. Akdoğu, E., \& Mackay, P. (2008). Investment and competition. Journal of Financial \& Quantitative Analysis, 43(2), 299-330. Amram, M., \& Kulatilaka, N. (1999). Real options. Milano, IT: Etas.

Ashuri, B., Kashani, H., Molenaar, K. R., Lee, S., \& Lu, J. (2012). Risk-neutral pricing approach for evaluating BOT highway projects with government minimum revenue guarantee options. Journal of Construction Engineering \& Management, 138(4), 545-557.

Avanzi, B., Bicer, I., De Treville, S., \& Trigeorgis, L. (2013). Real option at the interface of finance and operations: exploiting embedded supply-chain real options to gain competitiveness. European Journal of Finance, 19(7/8), 760-778.

Baduns, E. (2013). Realistic investment valuation: a comprehensive real options model. Journal of Business Management, 7, 58-71.

Baker, H. K., Dutta, S., \& Saadi, S. (2011). Management views on real options in capital budgeting. Journal of Applied Finance, 21(1), 18-29.

Barton, K., \& Lawryshyn, Y. (2011). Integrating real options with managerial cash flow estimates. Engineering Economist, 56(3), 254-273.

Benaroch, M. (2002). Managing information technology investment risk: a real option perspective. Journal of Management Information Systems, 19(2), 43-84.

Benaroch, M., \& Kauffman, R. (1999). A case for using real options pricing analysis to evaluate information technology project investments. Information Systems Research, 10(1), 70-86.

Benaroch, M., Shah, S., \& Jeffery, M. (2006). On the valuation of multistage information technology investments embedding nested real options. Journal of Management Information Systems, 23(1), 239-261.

Bhattacharya, M., \& Wright, P. M. (2005). Managing human assets in an uncertain world: applying real options theory to HRM. International Journal of Human Resource Management, 16(6), 929-948.

Black, F., \& Scholes, M. (1973). The pricing of options and corporate liabilities. The journal of political economy, 81(3), 637-654

Borison, A. (2005). Real options analysis: where are the emperor's clothes? Journal of Applied Corporate Finance, 17(2), 17-31.

Bowman, E. H., \& Hurry, D. (1993). Strategy through the option lens: an integrated view of resource investments and the incremental-choice process. Academy of Management Review, 18, 760-782

Brennan, M. J., \& Trigeorgis, L. (2000). Project flexibility, agency, and competition: new developments in the theory and application of real options. New York, NY: Oxford University Press.

Bulan, L. T. (2005). Real options, irreversible investment and firm uncertainty: new evidence from US firms. Review of Financial Economics, 14(3), 255-279.

Bulan, L., Mayer, C., \& Somerville, C. T. (2009). Irreversible investment, real options, and competition: evidence from real estate development. Journal of Urban Economics, 65(3), 237-251.

Burnetas, A., \& Ritchken, P. (2005). Option pricing with downward-sloping demand curves: the case of supply chain options. Management Science, 51(4), 566-580.

Chi, T., \& McGuire, D. J. (1996). Collaborative ventures and value of learning: integrating the transaction cost and strategic option perspectives on the choice of market entry modes. Journal of International Business Studies, 27, 285-307.

Cox, J. C., \& Rubinstein, M. (1985). Options markets. New Jersey, NJ: Prentice-Hall.

Cox, J. C., Ross, S., \& Rubinstein, M. (1979). Option pricing: a simplified approach. Journal of Financial Economics, 7(3), $229-263$

Damodaran, A. (2000). The promise of real options. Journal of Applied Corporate Finance, 13(2), $28-39$.

Del Giudice, M., Della Peruta, M. R., \& Maggioni, V. (2013). Collective knowledge and organizational routines within academic communities of practice: an empirical research on science-entrepreneurs. Journal of the Knowledge Economy, 4(3), 260-27.

Del Giudice, V., Passeri, A., De Paola, P., \& Torrieri, F. (2014). Estimation of risk-return for real estate investments by applying Ellwood's model and real options analysis: an application to the residential real estate market of Naples. Applied Mechanics \& Materials, 651-653, 1570-1575.

Denison, C. A., Farrell, A. M., \& Jackson, K. E. (2012). Managers incorporation of the value of real options into their longterm investment decisions: an experimental investigation. Contemporary Accounting Research, 29(2), 590-620.

Dotsis, G., Makropoulou, V., \& Markellos, R. N. (2012). Investment under uncertainty and volatility estimation risk. Applied Economics Letters, 19(2), 133-137.

Driffill, J., Kenc, T., \& Sola, M. (2013). Real options with priced regime-switching risk. International Journal of Theoretical \& Applied Finance, 16(5), 1-30.

Ericsson, J., \& Reneby, J. (2005). Estimating structural bond pricing models. The Journal of Business, 78(2), 707-735.

Eschenbach, T., Lewis, N., Henrie, M., Baker, E., \& Hariman, J. C. (2007). Real option and real engineering projects. Engineering Management Journal, 19(4), 11-19.

Fabozzi, F. J., Shiller, R. J., \& Tunaru, R. S. (2012). A pricing framework for real estate derivatives. European Financial Management, 18(5), 762-789.

Faiferlick, C. J., Reichert, T., Andreoli, B., Ackerman, R. E., Chmiel, P., \& Odden, L. (2004). Using real options to transfer price research-based intangibles. International Tax Journal, 30(3), 111-120.

Fama, E. F., \& French, K. R. (1996). Multifactor explanations of asset pricing anomalies. Journal of Finance, 51, 55-84.

Farrow, S. (2004). Using risk assessment, benefit-cost analysis, and real options to implement a precautionary principle. Risk Analysis: An International Journal, 24(3), 727-735.

Favato, G. (2008). Relevance of real options to corporate investment decisions. ICFAl Journal of Derivatives Markets, 5(3), 91-103.

Fichman, R. G. (2004). Real options and IT platform adoption: implications for theory and practice. Information Systems Research, 15(2), 132-154.

Folta, T. B. (1998). Governance and uncertainty: the tradeoff between administrative control and commitment. Strategic Management Journal, 19(11), 1007-1028. 
Ford, D. N., Lander, D. M., \& Voyer, J. J. (2002). A real options approach to valuing strategic flexibility in uncertain construction projects. Construction Management \& Economics, 20(4), 343-351.

Franklin, S. L., \& Diallo, M. (2012). Valuing real options for network investment decisions and cost-based access pricing. Engineering Economist, 57(4), 223-246.

Garg, A. K., \& Kumar, K. (2014). Option pricing models of private equity valuation: a comparative analysis. IUP Journal of Applied Finance, 20(3), 28-40.

Grasselli, M. R. (2011). Getting real with real options: a utility-based approach for finite-time investment in incomplete markets. Journal of Business Finance \& Accounting, 38(5/6), 740-764.

Grullon, G., Lyandres, E., \& Zhdanov, A. (2012). Real options, volatility, and stock returns. Journal of Finance, 67(4), 1499-1537.

Gunther McGrath, R., \& Nerkar, A. (2004). Real options reasoning and a new look at the R\&D investment strategies of pharmaceutical firms. Strategic Management Journal, 25(1), 1-21.

Hartmann, M., \& Hassan, A. (2006). Application of real options analysis for pharmaceutical R\&D project valuation - empirical results from a survey. Research Policy, 35(3), 343-354.

Henderson, V., \& Hobson, D. G. (2002). Real options with constant relative risk aversion. Journal of Economic Dynamics and Control, 27(2), 329-355.

Henseler, J., \& Roemer, E. (2013). "Let's wait and see!" The real option to switch as a new element of customer value. Schmalenbach Business Review, 65(2), 112-136.

Huang, Y. C., \& Chen, S. C. (2002). Warrants pricing: stochastic volatility vs. Black-Scholes. Pacific-Basin Finance Journal, 10(4), 393-409.

Hult, G. T. M., Craighead, C. W., \& Ketchen, D. J., Jr. (2010). Risk uncertainty and supply chain decisions: a real option perspective. Decision Sciences, 41(3), 435-458.

Jiao, Y. Y., Du, J., \& Jiao, J. (2007). A financial model of flexible manufacturing systems planning under uncertainty: identification, valuation and applications of real options. International Journal of Production Research, 45(6), 1389-1404.

Kim, D. Y., Ashuri, B., \& Han, S. H. (2013). Financial valuation of investments in international construction markets: realoptions approach for market-entry decisions. Journal of Management in Engineering, 29(4), 355-368.

Kodukula, P., \& Papudesu, C. (2006). Project valuation using real options: a practitioner's guide. New York, NY: J. Ross Publishing.

Kogut, B. (1991). Joint ventures and the option to expand and acquire. Management Science, 37, 19-33.

Kogut, B., \& Kulatilaka, N. (1994). Operating flexibility, global manufacturing, and the option value of a multinational network. Management Science, 40, 123-139.

Kogut, B., \& Kulatilaka, N. (2004). Real options pricing and organizations: the contingent risks of extended theoretical domains. Academy of Management Review, 29(1), 102-110.

Krychowski, C., \& Quélin, B. V. (2010). Real options and strategic investment decisions: can they be of use to scholars? Academy of Management Perspectives, 24(2), 65-78.

Kumaraswamy, A. (1996). A real options perspective on firms R\&D investments. New York: Doctoral dissertation, New York University.

Lankton, N., \& Luft, J. (2008). Uncertainty and industry structure effects on managerial intuition about information technology real options. Journal of Management Information Systems, 25(2), 203-240.

Lele, D., Lian, X., Leiwei, L., Tuo, C., \& Minghui, W. (2014). Numerical simulation of Black-Scholes model by finite difference method. Applied Mechanics \& Materials, 513-517, 4090-4093.

Lombardi, R., Trequattrini, R., \& Battista, M. (2014). Systematic errors in decision making processes: the case of the Italian Serie A football championship. International Journal of Applied Decision Sciences, 7(3), 239-254.

Madhani, P. M. (2013). Organizational flexibility: real option approach. SCMS Journal of Indian Management, 10(3), 43-54

Maggioni, V., \& Del Giudice, M. (2011). Relazioni sistemiche tra imprenditorialità interna e gemmazione d'impresa: una ricerca empirica sulla natura cognitiva delle nuove imprese. Sinergie, 71, 171-197.

Maklan, S., Knox, S., \& Ryals, L. (2005). Using real options to help build the business case for CRM investment. Long Range Planning, 38(4), 393-410.

Makhudu, T. (2011). Real options and property development decision making. Real Estate Finance, 27(5), 5-16.

Mattar, M. H., \& Cheah, C. Y. J. (2006). Valuing large engineering projects under uncertainty: private risk effects and real options. Construction Management \& Economics, 24(8), 847-860.

Maylor, H., \& Blackmon, K. (2005). Researching business and management. New York, NY: Palgrave Macmillan.

McCarter, M. W., Mahoney, J. T., \& Northcraft, G. B. (2011). Testing the waters: using collective real options to manage the social dilemma of strategic alliances. Academy of Management Review, 36(4), 621-640.

Merton, R. (1973). Theory of rational option pricing. Bell Journal of Economics and Management Science, 4, 141-183.

Ming-Cheng, W., \& Yen, S. H. (2007). Pricing real growth options when the underlying assets have jump diffusion processes: the case of R\&D investments. R\&D Management, 37(3), 269-276.

Moore, L., \& Juh, S. (2006). Derivative pricing 60 years before Black-Scholes: evidence from the Johannesburg Stock Exchange. Journal of Finance, 61(6), 3069-3098.

Morris, H., \& Limon, A. (2010). A multilevel approach to solving the Black-Scholes equation. International Journal of Theoretical \& Applied Finance, 13(3), 403-414.

Myers, M. D. (2013). Qualitative research in business \& management. London, UK: Sage.

Myers, S. C. (1977). Determinants of corporate borrowing. Journal of financial economics, 5(2), 147-175.

Oppenheimer, P. H. (2002). A critique of using real options pricing models in valuing real estate projects and contracts. Briefings in Real Estate Finance, 2(3), 221-235.

Palacios-Marqués, D., Soto-Acosta, P., \& Merigó, J. M. (2015). Analyzing the effects of technological, organizational and competition factors on web knowledge exchange in SMEs. Telematics and Informatics, 32(1), 23-32.

Park, T., Kim, B., \& Kim, H. (2013). Real option approach to sharing privatization risk in underground infrastructures. Journal of Construction Engineering \& Management, 139(6), 685-693.

Parthasarathy, K. V., \& Madhumathi, R. (2010). Real options analysis in valuation of commercial project: a case study. IUP Journal of Infrastructure, $8(1 / 2), 7-25$. 
Peng, F. (2010). A note on applying option pricing theory to emerging mortgage and mortgage-backed securities markets. Applied Economics Letters, 17(9), 881-885.

Pomykacz, M., \& Olmsted, C. (2013). Options in real estate valuation. Appraisal Journal, 81(3), $227-238$.

Porter, M. E. (1980). Competitive strategy: techniques for analyzing industries and competitors. New York, NY: Free Press.

Pyo, U. (2008). Real option pricing and bounds in incomplete markets. Engineering Economist, 53(1), 4-41.

Ren-Raw, C., San-Lin, C., \& Yang, T. T. (2002). Option pricing in a multi-asset, complete market economy. Journal of Financial \& Quantitative Analysis, 37(4), 649-666.

Sewalk, S., \& Dai, Q. (2014). Valuing real options in hospital expansions using vertical phasing. Real Estate Finance, 30(4), 156-166.

Singh, V. K. (2014). Competency of Monte Carlo and Black-Scholes in pricing Nifty index options: a vis-a-vis study. Monte Carlo Methods and Applications, 20(1), 61-77.

Soto-Acosta, P., Casado-Lumbreras, C., \& Cabezas-Isla, F. (2010). Shaping human capital in software development teams: the case of mentoring enabled by semantics. IET Software, 4(6), 445-452.

Tompkins, R. G. (2001). Implied volatility surfaces: uncovering regularities for options on financial futures. The European Journal of Finance, 7(3), 198-230

Trequattrini, R., Russo, G., \& Lombardi, R. (2012a). Defining business network international. Journal of Business Research and Management, 3(1), 29-34.

Trequattrini, R., Russo, G., \& Lombardi, R. (2012b). Network governance: organisational and legal profiles. Corporate Ownership \& Control, 9(4), 346-350.

Trequattrini, R., Russo, G., \& Lombardi, R. (2012c). The crisis of company networks and tools for its prediction. International Business Research, 5(10), 46-55.

Triantis, A., \& Borison, A. (2001). Real options: state of the practice. Journal of Applied Corporate Finance, 14(2), 8-24.

Wanetick, D. (2013). What is the real value in real options? Licensing Journal, 33(3), 7-10.

Wang, J., \& Hwang, W. L. (2007). A fuzzy set approach for R\&D portfolio selection using a real options valuation model. Omega, 35(3), 247-257.

Yin, R. (1994). Case study research. Thousand Oaks, CA: Sage Publication.

Yonggang X. \& Mingli Z. (2014). Application of Option-based Pricing Model in Investment Decision. Advanced Materials Research, 926, 3762-3765.

\section{Submit your manuscript to a SpringerOpen ${ }^{\circ}$ journal and benefit from:}

- Convenient online submission

- Rigorous peer review

- Immediate publication on acceptance

- Open access: articles freely available online

- High visibility within the field

Retaining the copyright to your article

Submit your next manuscript at $\gg$ springeropen.com 